\title{
Evaluation of essential oils against Sitophilus zeamais (Motshulsdy) (Coleoptera: Curculionidae)
}

\author{
Udomporn Pangnakorn ${ }^{1 *}$ and Sombat Chuenchooklin ${ }^{2}$ \\ ${ }^{1}$ Department of Agricultural Science, Faculty of Agriculture Natural Resources and Environment/ Center of Academic \\ Excellence in Postharvest technology, Naresuan University, Thailand. \\ ${ }^{2}$ Department of Civil Engineering, Faculty of Engineering/ Water Resources Research Center, Naresuan University, \\ Thailand.
}

Accepted 23 April, 2018

\begin{abstract}
The objective of the current study was to determine the fumigant toxicity of essential oils for control stored product insects pest. Essential oils from ten plant species currently found in Thailand: pine (Pinus Palustris), lemon grass (Cymbopogon citratus Stapf), peppermint (Mentha Piperita), citronella grass (Cymbopogon nardus Linn), sweet acacia (Acacia farnesiana), cinnamon (Cinnamomum verum J.S. Presl), sweet orange (Citrus sinensis Pers), basil (Ocimum basilicum L.), clove (Syzygium aromaticum L.), and star anise (Illicium verum Hook) were extracted by steam distillation and tested for their insecticidal activities against maize weevil (Sitophilus zeamais Motshulsdy). Fumigant toxicity test was evaluated on adult of the maize weevil under laboratory conditions. Mortality of the maize weevil was observed and recorded every $12 \mathrm{~h}$ until $72 \mathrm{~h}$. Responses varied with the test applied 100 and $10 \mu \mathrm{l}$ of essential oils from the ten plants species on the tested insects. Three of the essential oils (sweet acacia, basil and star anise) showed high toxicity and were selected for the residuality test to mortality by contact with a surface of treated petri dish and glass jar. The results revealed that diluted $7.5 \mu \mathrm{l}$ and $205.0 \mu \mathrm{l}$ of essential oils from three plants (star anise, basil and sweet acacia) achieved a high mortality of the tested insects at $100 \%$ within $36 \mathrm{~h}$ after exposure to surface of treated petri dish and glass jar respectively.
\end{abstract}

Keywords: Essential oils, fumigant toxicity, maize weevil Sitophilus zeamais (Motshulsdy), mortality.

*Corresponding author. E-mail: udompornp@nu.ac.th. Tel: + 66841792992.

\section{INTRODUCTION}

According to most of food products lost to various pests during post-harvest storage, consumers demand more natural processed products with long shelf-life but without chemical preservatives. Maize (Zea mays L.), rice and wheat are the three most important cereal crops worldwide (Regnault, 1997). Maize damage by Sitophilus zeamais causes food loss, increased poverty, and lower nutritional values of grain, increased malnutrition, reduced weight and market values (Keba and Sori, 2013). And also S. zeamais reduced germination percentage and maize production as most farmers in developing countries store grain and seed together (Pingali and Pandey, 2001).
Maize weevil, Sitophilus zeamais (Motschulsky), is a serious pest of economic importance in stored products in tropical and subtropical countries; infestation often starts in the field, but serious damage is done during maize storage (Suleiman et al., 2015; Fikremariam et al., 2009; Muzemu et al., 2013). It is the damage to grain by feeding activities of the adults and the development of immature stages within the grain. This not only reduces the grain quality but also produces a considerable amount of grain dust mixed with frass (Longstaff, 2010). It causes to weight loss of 20 to $90 \%$ for untreated maize in tropical countries (Giga et al., 1991). Maize is stored in commercial structures, with proper monitoring of 
temperature and moisture content to control pests in developed countries. But maize is often stored in traditional structures with no environmental control and usually without chemical protectants and usually without chemical protectants in tropical countries (Dhliwayo and Pixley, 2003). Fumigant such as methyl bromide and phosphine are still the most effective for the protection from insect infestation of stored food, feedstuffs, and other agricultural commodities (EPA, 2001). Some stored product insects are found to have developed resistance to methyl bromide and phosphine (Champ and Dyte, 1977).

The use of natural compounds from plants instead synthetic chemical pesticides is an alternative that can reduce the agriculture impact on the environment (Vanichpakorn et al., 2010). The choice of native species as source of oil and/ or extracts employed in pest control could be a strategy to their sustainable use by local communities, and consequently contribute to their conservation. Plant may provide potential alternatives to used for control insect agents because they constitute a rich source of bioactive chemicals (Wink, 1993). Numerous plants have been reported to have a variety of biological activities against insects including insecticidal, repellent, antifeedant, fumigant, growth regulatory, antiovipostion activities (Isman, 2006; Ukeh et al., 2010). Moreover, plant based insecticides often contain a mixture of active substances, which can delay or prevent resistance development (Wang et al., 2007). Plant products can be used for insect pest control in form of essential oils. Aim of this study was carried out to evaluate the fumigant toxicity from ten plants species and three essential oils were assessed against adults of maize weevil, Sitophilus zeamais Motshulsdy under laboratory conditions.

\section{MATERIALS AND METHODS}

\section{Insect preparation}

Maize weevil, Sitophilus zeamais (Motschulsky), was collected from maize storage silos in Phitsanulok province, Thailand, and reproduced in $1000 \mathrm{ml}$ plastic containing maize (Zea mays L.) as a source of food. The insects were maintained in the container at a room temperature of $30 \pm 1^{\circ} \mathrm{C}$ and $75 \% \mathrm{RH}$. They were laboratoryreared with laid eggs on maize, one week after laying eggs, the insect parents were removed. The eggs were kept in the same condition until adult emergence. Ten to fourteen-day olds of adults were used for bioassay tests.

\section{Plants extract preparation}

The essential oils of ten plant species: pine (Pinus palustris), lemon grass (Cymbopogon citratus Stapf), peppermint (Mentha piperita), citronella grass (Cymbopogon nardus Linn), sweet acacia (Acacia farnesiana), cinnamon (Cinnamomum verum J.S. Presl), sweet orange (Citrus sinensis Pers), basil (Ocimum basilicum L.), clove (Syzygium aromaticum L.), and star anise (Illicium verum Hook) were extracted from aerial parts of the plants by steam distillation using distilled water (Vogel et al., 1997). Subsequently, the oils were collected in glass recipient and kept in amber colored glass containers at $4^{\circ} \mathrm{C}$ until the subsequent assays. Pure essential oils were employed in all the tests. The samples were subjected to maize weevil S. zeamais (Motshulsdy). Tween 80 was used for emulsion to stabilize the essential oils before testing.

\section{Insects bioassay test}

\section{Fumigant toxicity assay}

This bioassay employed the methodology of Pires et al. (2006) cited by Jessica et al. (2010) which consisted of applying 0 (control), 1000, 100 and $10 \mu \mathrm{l}$ of the ten essential oils on Whatman $\mathrm{N}^{\circ} 10$ filter paper (Whatman, Maidstone, Kent, UK), which were cut into $3-\mathrm{cm}$ diameter pieces and fixed under the petri dish. Filter papers were impregnated with a series of concentrations of each essential oil. The same procedure was used for the control with filter paper without treatment and placed on the petri dish and then the ten unsexed adult insects was placed on the petri dish after the oils evaporated (10 insects/petri dish). There were four replicates of each treatment. The experimental units were kept in laboratory at a room temperature of $30 \pm 1^{\circ} \mathrm{C}$. Assessments of mortality were made at $12,24,36,48,60$ and $72 \mathrm{~h}$ of exposure.

\section{Mortality by contact with a surface of the treated container (petri dish)}

The methodology of Kouninki et al.(2007) was used. The high toxicities three from ten essential oils were selected to evaluate doses of oils were star anise (Illicium verum Hook), basil (Ocimum basilicum L.) and sweet acacia (Acacia farnesiana). The diluted of the three essential oils, applying 0 (control), 2.5, 5.0 and $7.5 \mu \mathrm{l}$ (using the filter paper diffusion method with exposed into petri dish). A solution of essential oils in acetone (99\% purity), at the required concentration of each treatment was applied on petri dish with $5 \mathrm{~g}$ of maize grain. Each petri dish was infested 10 unsexed adult insects, and stored in a room temperature of $30 \pm 1{ }^{\circ} \mathrm{C}$. Each treatment was carried out in 4 replicates. The mortality was assessed at $12,24,48$ and $72 \mathrm{~h}$ exposure to the toxic.

\section{Mortality by contact with a surface of the treated container (glass jar)}

The methodology of Kouninki et al. (2007) was used, with slight modifications that consisted of using $2600 \mathrm{~cm}^{3}$ glass jar (using the filter paper diffusion method with exposed into the jar) and applying 68, 137 and $205 \mu \mathrm{l}$ instead of $2.5,5.0$ and $7.5 \mu \mathrm{l}$, respectively. A solution of the three essential oils in acetone, at the required concentration applied on $6 \mathrm{~cm}$ of filter paper and place on the jar. The jar was agitated for $1 \mathrm{~min}$ for the oil to cover the interior surface. The oil was allowed to evaporate at ambient temperature for $1 \mathrm{~h}$, then 10 unsexed adult insects were placed in each jar with $5 \mathrm{~g}$ of maize. Four replicates were made per treatment. The treatments were kept at room temperature at $30 \pm 1^{\circ} \mathrm{C}$. Insect mortality was assessed at 24, 48 and $72 \mathrm{~h}$ of exposure to the essential oils.

As the mortality rate in the control was lower than $5 \%$, this was corrected with the Abbott formula (Abbott, 1925). An insect was considered dead when there was no movement after prodding it with a dissection needle.

$$
\% \text { Mortality }=\frac{\% \text { test mortality }-\% \text { control mortality }}{100-\% \text { control mortality }} \times 100
$$




\section{Statistical analysis}

The significance of treatments was calculated by one way Analysis of Variance (ANOVA) and effective treatment was separated by the Duncan's New Multiple Ranges Test (DMRT). Differences between means were considered significant at $P<0.05$.

\section{RESULTS AND DISCUSSION}

\section{Fumigant toxicity of 10 essential oils against maize weevil Sitophilus zeamais (Motshulsdy)}

Fumigant toxicity of ten essential oils with 100 and $10 \mu \mathrm{l}$ as shown in Tables 1 and 2 . The mortality of $S$. zeamais increased with the increase of volume of the oils and exposure time. Almost of the essential oils show fumigant toxicity with high mortalities ranging from 82.5 to $100 \%$ at $72 \mathrm{~h}$ after treatment with $100 \mu \mathrm{l}$ (Table 1). When the decrease essential oils to $10 \mu \mathrm{l}$ were applied on tested insects, the high fumigant toxicity occurred on the three essential oils against $S$. zeamais with significant differences $(P<0.01)$. Only three of essential oils showed significantly higher fumigant toxicity against $S$. zeamais than the other treatment with mortality of $100 \%$ at $72 \mathrm{~h}$, whereas the other essential oils could not achieve up to $100 \%$ insect mortality. Sweet acacia (Acacia farnesiana), basil (Ocimum basilicum L.) and star anise (Illicium verum Hook) achieved $100 \%$ mortality of $S$. zeamais within $36 \mathrm{~h}$ after treatment. No mortality was observed in the untreated controls (Table 2). Therefore the three essential oils were selected to apply for testing mortality by contact with a surface of treated container with petri dish and glass jar as shown on Tables 3 and 4 , respectively.

In general, mortality increased with increased exposure time to the essential oil, which concurs with Bittner et al. (2008). The $10 \mu \mathrm{l}$ of essential oils from sweet acacia, basil and star anise exceeded $100 \%$ mortality at $36 \mathrm{~h}$ (Table 2). Particularly, the sweet acacia caused $100 \%$ mortality at $24 \mathrm{~h}$ after treatment, meantime mortality of basil and star anise was $87.5 \%$. Similarly, it was observed in the fumigant action bioassay on $S$. zeamais (Motschulsky) by Jessica et al. (2010) that $35 \mu \mathrm{l}$ of Peumus boldus Molina oil in a volume of $0.15 \mathrm{~L}$ has a rapid toxic effect, producing $100 \%$ mortality in $6 \mathrm{~h}$. At 24 $\mathrm{h}$, the treatments higher than $20 \mu \mathrm{l}$ of the essential oil in $0.15 \mathrm{~L}$ caused $100 \%$ mortality. Also the mortality of $S$. zeamais after $24 \mathrm{~h}$ exposure to different dosage of $C$. dinisii oil demonstrated by Vedovatto et al. (2015). Vogel et al. (2005) reported that the essential oil of Rosmarinus officinalis L. and Eucalyptus blakelyi Maiden had fumigant action against the mite Tetranychus urticae Koch (Miresmailli et al., 2006); Sitophilus oryzae L. and Tribolium castaneum Herbst (Lee et al., 2003).

Table 1. Fumigant toxicities of 10 essential oils $(100 \mu \mathrm{l})$ on mortality (\%) Sitophilus zeamais Motshulsdy.

\begin{tabular}{|c|c|c|c|c|c|c|c|}
\hline \multirow{2}{*}{ Treatment } & \multicolumn{7}{|c|}{$\%$ Mortality } \\
\hline & $12 \mathrm{~h}$ & $24 \mathrm{~h}$ & $36 \mathrm{~h}$ & $48 \mathrm{~h}$ & $60 \mathrm{~h}$ & $72 \mathrm{~h}$ & df \\
\hline Control (water) & $0^{d}$ & $0^{c}$ & $0^{c}$ & $0^{c}$ & $0^{c}$ & $0^{\mathrm{C}}$ & 0 \\
\hline Pine oil & $15.0^{d}$ & $22.5^{\mathrm{c}}$ & $70.0^{\mathrm{ab}}$ & $87.5^{\mathrm{ab}}$ & $97.5^{\mathrm{a}}$ & $97.5^{\mathrm{a}}$ & * \\
\hline Lemon grass & $0^{d}$ & $0^{c}$ & $7.5^{\mathrm{c}}$ & $7.5^{\mathrm{c}}$ & $10.0^{c}$ & $12.5^{\mathrm{c}}$ & ns \\
\hline Peppermint & $92.5^{\mathrm{a}}$ & $100.0^{\mathrm{a}}$ & $100.0^{\mathrm{a}}$ & $100.0^{\mathrm{a}}$ & $100.0^{\mathrm{a}}$ & $100.0^{\mathrm{a}}$ & * \\
\hline Citronella grass & $5.0^{\mathrm{d}}$ & $17.5^{\mathrm{c}}$ & $22.5^{\mathrm{bc}}$ & $35.0^{\mathrm{bc}}$ & $47.5^{\mathrm{bc}}$ & $55.0^{\mathrm{bc}}$ & ns \\
\hline Sweet acacia & $55.0^{\mathrm{bc}}$ & $75.0^{\mathrm{ab}}$ & $95.0^{\mathrm{a}}$ & $100.0^{\mathrm{a}}$ & $100.0^{\mathrm{a}}$ & $100.0^{\mathrm{a}}$ & * \\
\hline Cinnamon & $22.5^{\mathrm{cd}}$ & $45.0^{\mathrm{bc}}$ & $62.0^{\mathrm{bc}}$ & $69.5^{\mathrm{bc}}$ & $79.5^{\mathrm{ab}}$ & $84.5^{\mathrm{ab}}$ & * \\
\hline Sweet orange & $65.0^{\mathrm{ab}}$ & $70.0^{\mathrm{ab}}$ & $77.5^{\mathrm{ab}}$ & $80.0^{\mathrm{ab}}$ & $80.0^{\mathrm{ab}}$ & $82.5^{\mathrm{ab}}$ & * \\
\hline Basil oil & $80.0^{\mathrm{ab}}$ & $97.5^{\mathrm{a}}$ & $97.5^{\mathrm{a}}$ & $97.5^{\mathrm{a}}$ & $97.5^{\mathrm{a}}$ & $97.5^{\mathrm{a}}$ & * \\
\hline Clove Oil & $32.5^{\mathrm{cd}}$ & $57.5^{\mathrm{bc}}$ & $82.5^{\mathrm{ab}}$ & $82.5^{\mathrm{ab}}$ & $82.5^{\mathrm{ab}}$ & $82.5^{\mathrm{ab}}$ & * \\
\hline Star anise & $70.0^{\mathrm{ab}}$ & $85.0^{\mathrm{ab}}$ & $97.5^{\mathrm{a}}$ & $100.0^{\mathrm{a}}$ & $100.0^{\mathrm{a}}$ & $100.0^{\mathrm{a}}$ & * \\
\hline
\end{tabular}

$\mathrm{ns}=$ non significant; * = significant difference, means (followed by the same letter) are not significantly different at $5 \%$ level by DMRT.

\section{Mortality by contact with a surface of treated container (petri dish) with the 3 selected essential oils}

The three selected of essential oils (sweet acacia , basil and star anise) were applied on petri dish, the mortality by contact with a surface of the treated petri dish showed mortality increases with increases volume of the essential oil. At $12 \mathrm{~h}, \mathrm{~S}$. zeamais response to the sweet acacia oil with mortality was $75,92.5$ and $95 \%$ at treatment of 2.5 , 5.0 and $7.5 \mu \mathrm{l}$ respectively. However, star anise oil given the low mortality to $S$. zeamais only 22.5 and $30.0 \%$ at treatment of 2.5 and $5.0 \mu \mathrm{l}$ respectively, but sharply increase reached a mortality to $100 \%$ at treatment of 7.5 $\mu \mathrm{l}$ at the first $12 \mathrm{~h}$ after testing. There was no mortality in the untreated control (Table 3). In 2003, some researcher 
Table 2. Fumigant toxicities of essential oils $(10 \mu \mathrm{l})$ on Sitophilus zeamais Motshulsdy.

\begin{tabular}{|c|c|c|c|c|c|c|c|}
\hline \multirow{2}{*}{ Treatment } & \multicolumn{7}{|c|}{$\%$ Mortality } \\
\hline & $12 \mathrm{~h}$ & $24 \mathrm{~h}$ & $36 \mathrm{~h}$ & $48 \mathrm{~h}$ & $60 \mathrm{~h}$ & $72 \mathrm{~h}$ & df \\
\hline Control (water) & $0^{d}$ & $0^{c}$ & $0^{c}$ & $0^{d}$ & $0^{d}$ & $0^{d}$ & $\mathrm{~ns}$ \\
\hline Pine oil & $2.5^{d}$ & $15.0^{\mathrm{bc}}$ & $17.5^{\mathrm{bc}}$ & $17.5^{\mathrm{c}}$ & $17.5^{\mathrm{b}}$ & $17.5^{\mathrm{cd}}$ & ns \\
\hline Lemon grass & $2.5^{\mathrm{d}}$ & $2.5^{\mathrm{c}}$ & $5.0^{\mathrm{bc}}$ & $7.5^{\mathrm{cd}}$ & $7.5^{\mathrm{c}}$ & $10.0^{d}$ & ns \\
\hline Peppermint & $30.0^{c}$ & $32.5^{\mathrm{b}}$ & $37.5 .0^{\mathrm{b}}$ & $40.0^{\mathrm{b}}$ & $50.0^{\mathrm{b}}$ & $70.0^{\mathrm{ab}}$ & * \\
\hline Citronella grass & $2.5^{d}$ & $5.0^{\mathrm{C}}$ & $5.0^{\mathrm{bc}}$ & $7.5^{\mathrm{cd}}$ & $10.0^{c}$ & $15.0^{\text {cd }}$ & ns \\
\hline Sweet Acacia & $95.0^{\mathrm{a}}$ & $100.0^{a}$ & $100.0^{a}$ & $100.0^{a}$ & $100.0^{a}$ & $100.0^{a}$ & * \\
\hline Cinnamon & $17.5^{\mathrm{cd}}$ & $22.5^{\mathrm{bc}}$ & $32.5^{\mathrm{b}}$ & $40.0^{b}$ & $52.5^{b}$ & $52.5^{\mathrm{bc}}$ & * \\
\hline Sweet orange & $0^{d}$ & $0^{c}$ & $0^{c}$ & $0^{d}$ & $7.5^{\mathrm{c}}$ & $17.5^{\mathrm{cd}}$ & ns \\
\hline Basil oil & $62.5^{\mathrm{bc}}$ & $87.5^{\mathrm{ab}}$ & $100.0^{a}$ & $100.0^{\mathrm{a}}$ & $100.0^{\mathrm{a}}$ & $100.0^{\mathrm{a}}$ & * \\
\hline Clove Oil & $10.0^{\mathrm{cd}}$ & $15.0^{\mathrm{bc}}$ & $32.5^{\mathrm{b}}$ & $35.0^{\mathrm{b}}$ & $47.5^{\mathrm{b}}$ & $50.0^{\mathrm{bc}}$ & ns \\
\hline Star anise & $50.0^{\mathrm{bc}}$ & $87.5^{\mathrm{ab}}$ & $100.0^{a}$ & $100.0^{a}$ & $100.0^{\mathrm{a}}$ & $100.0^{\mathrm{a}}$ & * \\
\hline
\end{tabular}

ns = non significant; * = significant difference, means (followed by the same letter) are not significantly different at $5 \%$ level by DMRT.

Table 3. Mortality (\%) of Sitophilus zeamais Motshulsdy exposed to petri dish surface treated with the 3 selected essential oils.

\begin{tabular}{|c|c|c|c|c|c|c|c|}
\hline \multirow{2}{*}{ Treatment } & \multicolumn{7}{|c|}{$\%$ Mortality } \\
\hline & $12 \mathrm{~h}$ & $24 \mathrm{~h}$ & $36 \mathrm{~h}$ & $48 \mathrm{~h}$ & $60 \mathrm{~h}$ & $72 \mathrm{~h}$ & df \\
\hline Control (water) & $0^{\mathrm{C}}$ & $0^{c}$ & $0^{\mathrm{C}}$ & $0^{\mathrm{C}}$ & $0^{c}$ & $0^{\mathrm{C}}$ & \\
\hline Sweet acacia oil $2.5 \mu \mathrm{l}$ & $75.0^{\mathrm{ab}}$ & $82.5^{\mathrm{ab}}$ & $82.5^{\mathrm{ab}}$ & $85.0^{\mathrm{ab}}$ & $87.5^{\mathrm{ab}}$ & $87.5^{\mathrm{ab}}$ & * \\
\hline Basil oil $2.5 \mu \mathrm{l}$ & $12.5^{\mathrm{b}}$ & $30.0^{\mathrm{b}}$ & $60.0^{\mathrm{ab}}$ & $62.5^{\mathrm{ab}}$ & $75.0^{\mathrm{ab}}$ & $75.0^{\mathrm{ab}}$ & * \\
\hline Star anise oil $2.5 \mu \mathrm{l}$ & $22.5^{\mathrm{b}}$ & $32.5^{\mathrm{b}}$ & $52.5^{\mathrm{ab}}$ & $55.0^{a b}$ & $60.0^{\mathrm{ab}}$ & $62.5^{\mathrm{ab}}$ & * \\
\hline Sweet acacia oil $5.0 \mu \mathrm{l}$ & $92.5^{\mathrm{a}}$ & $97.5^{\mathrm{a}}$ & $100.0^{\mathrm{a}}$ & $100.0^{\mathrm{a}}$ & $100.0^{\mathrm{a}}$ & $100.0^{a}$ & * \\
\hline Basil oil $5.0 \mu \mathrm{l}$ & $20.0^{\mathrm{b}}$ & $44.5^{\mathrm{ab}}$ & $69.5^{\mathrm{ab}}$ & $74.5^{\mathrm{ab}}$ & $74.5^{\mathrm{ab}}$ & $79.5^{\mathrm{ab}}$ & * \\
\hline Star anise oil $5.0 \mu \mathrm{l}$ & $30.0^{\mathrm{b}}$ & $67.5^{\mathrm{ab}}$ & $97.5^{\mathrm{a}}$ & $100.0^{\mathrm{a}}$ & $100.0^{a}$ & $100.0^{\mathrm{a}}$ & * \\
\hline Sweet acacia oil $7.5 \mu \mathrm{l}$ & $95.0^{\mathrm{a}}$ & $100.0^{\mathrm{a}}$ & $100.0^{\mathrm{a}}$ & $100.0^{\mathrm{a}}$ & $100.0^{\mathrm{a}}$ & $100.0^{\mathrm{a}}$ & * \\
\hline Basil oil $7.5 \mu \mathrm{l}$ & $35.0^{\mathrm{b}}$ & $55.0^{\mathrm{ab}}$ & $100.0^{\mathrm{a}}$ & $100.0^{\mathrm{a}}$ & $100.0^{\mathrm{a}}$ & $100.0^{\mathrm{a}}$ & * \\
\hline Star anise oil $7.5 \mu \mathrm{l}$ & $100.0^{\mathrm{a}}$ & $100.0^{\mathrm{a}}$ & $100.0^{\mathrm{a}}$ & $100.0^{\mathrm{a}}$ & $100.0^{\mathrm{a}}$ & $100.0^{\mathrm{a}}$ & * \\
\hline
\end{tabular}

* = significant difference, means (followed by the same letter) are not significantly different at $5 \%$ level by DMRT.

Table 4. Mortality (\%) of Sitophilus zeamais Motshulsdy exposed to $2600 \mathrm{~cm}^{3}$ glass jar surface treated with the 3 selected essential oils.

\begin{tabular}{|c|c|c|c|c|c|c|c|}
\hline \multirow{2}{*}{ Treatment } & \multicolumn{7}{|c|}{$\%$ Mortality } \\
\hline & $12 \mathrm{~h}$ & $24 \mathrm{~h}$ & $36 \mathrm{~h}$ & $48 \mathrm{~h}$ & $60 \mathrm{~h}$ & $72 \mathrm{~h}$ & df \\
\hline Control (water) & $0^{\mathrm{C}}$ & $0^{c}$ & $0^{\mathrm{C}}$ & $0^{c}$ & $0^{c}$ & $0^{\mathrm{C}}$ & \\
\hline Sweet acacia oil $68.0 \mu \mathrm{l}$ & $27.5^{\mathrm{b}}$ & $72.5^{\mathrm{ab}}$ & $82.5^{\mathrm{ab}}$ & $82.5^{\mathrm{ab}}$ & $82.5^{\mathrm{ab}}$ & $82.5^{\mathrm{ab}}$ & * \\
\hline Basil oil $68.0 \mu \mathrm{l}$ & $67.5^{\mathrm{ab}}$ & $85.0^{\mathrm{ab}}$ & $97.5^{\mathrm{a}}$ & $100.0^{a}$ & $100.0^{a}$ & $100.0^{a}$ & * \\
\hline Star anise oil $68.0 \mu \mathrm{l}$ & $72.5^{\mathrm{ab}}$ & $75.0^{\mathrm{ab}}$ & $90.0^{\mathrm{a}}$ & $97.5^{\mathrm{a}}$ & $100.0^{\mathrm{a}}$ & $100.0^{\mathrm{a}}$ & * \\
\hline Sweet acacia oil $137.0 \mu \mathrm{l}$ & $47.5^{\mathrm{ab}}$ & $62.5^{b}$ & $92.5^{\mathrm{a}}$ & $97.5^{\mathrm{a}}$ & $97.5^{\mathrm{a}}$ & $97.5^{\mathrm{a}}$ & * \\
\hline Basil oil $137.0 \mu \mathrm{l}$ & $57.5^{\mathrm{ab}}$ & $82.5^{\mathrm{ab}}$ & $100.0^{a}$ & $100.0^{\mathrm{a}}$ & $100.0^{a}$ & $100.0^{\mathrm{a}}$ & * \\
\hline Star anise oil $137.0 \mu \mathrm{l}$ & $57.5^{\mathrm{ab}}$ & $77.5^{\mathrm{ab}}$ & $100.0^{a}$ & $100.0^{a}$ & $100.0^{a}$ & $100.0^{a}$ & * \\
\hline Sweet acacia oil $205.0 \mu \mathrm{l}$ & $90.0^{\mathrm{a}}$ & $95.0^{\mathrm{a}}$ & $95.0^{\mathrm{a}}$ & $97.5^{\mathrm{a}}$ & $97.5^{\mathrm{a}}$ & $97.5^{\mathrm{a}}$ & * \\
\hline Basil oil $205.0 \mu \mathrm{l}$ & $87.5^{\mathrm{a}}$ & $90.0^{\mathrm{a}}$ & $100.0^{\mathrm{a}}$ & $100.0^{\mathrm{a}}$ & $100.0^{\mathrm{a}}$ & $100.0^{\mathrm{a}}$ & * \\
\hline Star anise oil $205.0 \mu \mathrm{l}$ & $100.0^{a}$ & $100.0^{a}$ & $100.0^{a}$ & $100.0^{a}$ & $100.0^{a}$ & $100.0^{a}$ & * \\
\hline
\end{tabular}

ns = non significant; * = significant difference, means (followed by the same letter) are not significantly different at $5 \%$ level by DMRT. 

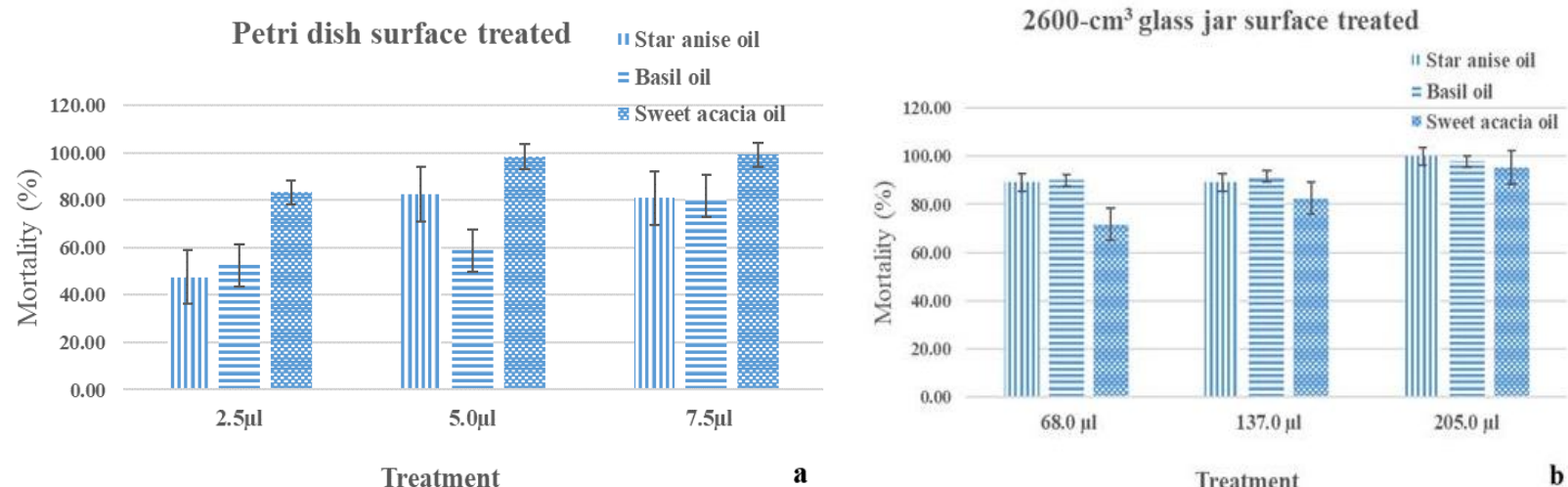

Figure 1. The effect of the 3 selected essential oils on \% mortality of Sitophilus zeamais Motshulsdy exposed to petri dish surface (a) and exposed to $2600 \mathrm{~cm}^{3}$ glass jar surface (b).
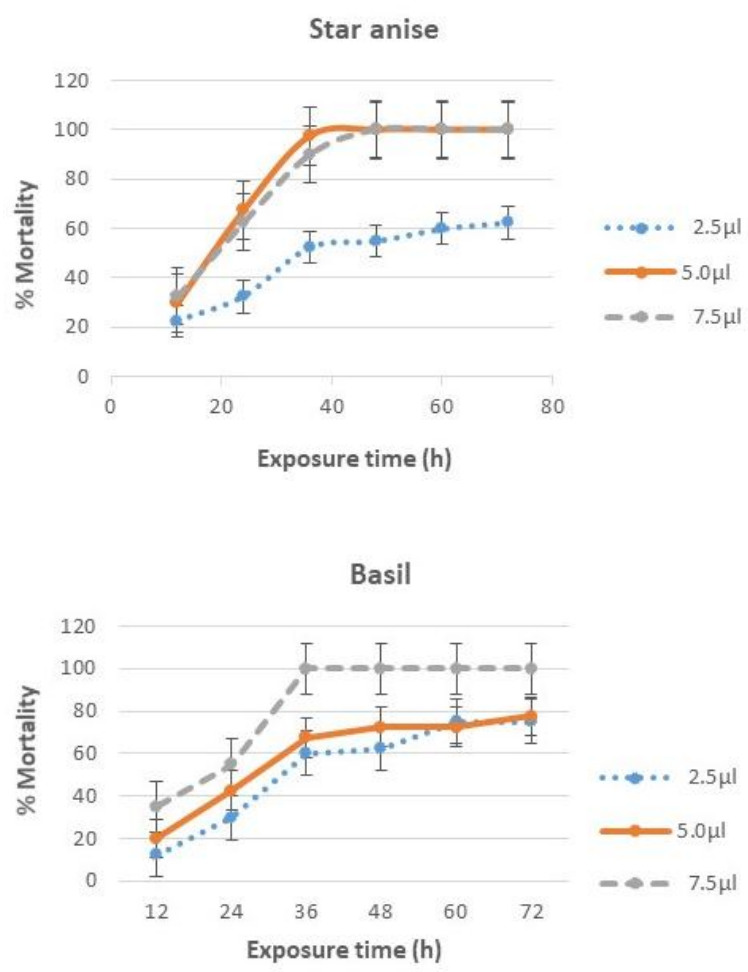

Sweet acacia

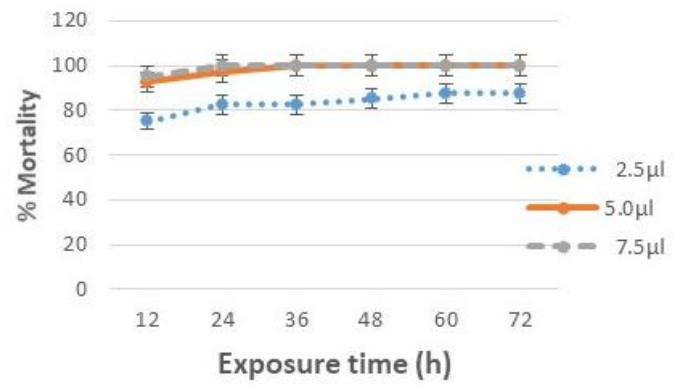

Star anise

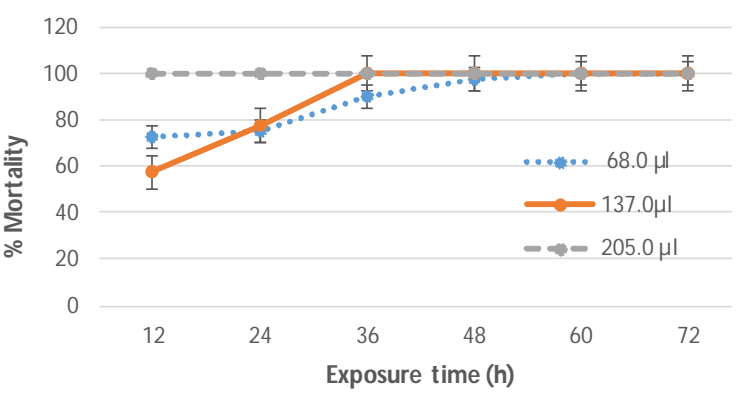

Basil

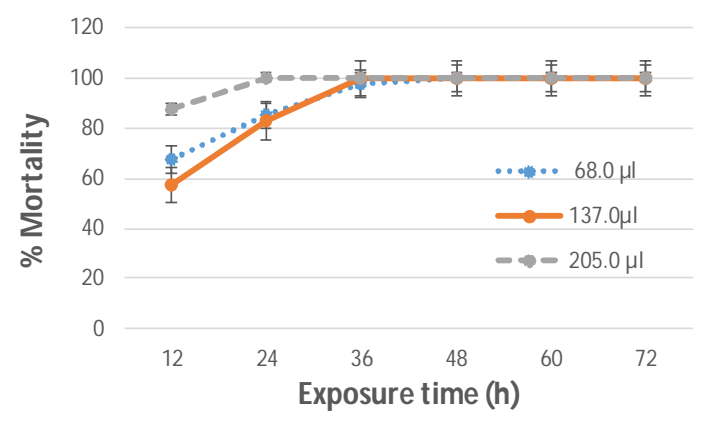

Sweet acacia

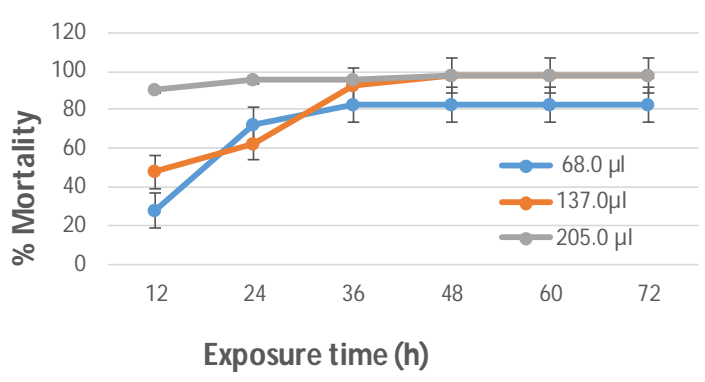

Figure 2. Percentage mortality of Sitophilus zeamais Motshulsdy exposed to various periods of time to the 3 selected essential oils on filter paper discs. 
point out a test with a filter paper diffusion method that cinnamon oil, mustard oil, and horseradish oil produced $100 \%$ mortality within 1 day after treatment of $0.7 \mathrm{mg} / \mathrm{cm}^{2}$ for insecticidal activity against adult Sitophilus oryzae. Additional, extracts of Acorus calamus, cinnamon oil $C$. cassia and C. sieboldii caused $100 \%$ mortality within 1 day after treatment of $3.5 \mathrm{mg} / \mathrm{cm}^{2}$ against adult Callosobruchus chinensis L. (Kim et al., 2003).

\section{Mortality by contact with a surface of treated container (glass jar) with the 3 selected essential oils}

Additional, the treated container was slightly modified that consisted of using $2600 \mathrm{~cm}^{3}$ glass jar instead of the petri dish and applying of three selected essential oils was 68.0, 137.0 and $205.0 \mu \mathrm{l}$. Essential oil of star anise at treatment of $205.0 \mu \mathrm{l}$ resulted the highest of mortality of $100 \%$ at $12 \mathrm{~h}$. No mortality was observed in the untreated controls (Table 4). As the time increases between observations the mortality of adults $S$. zeamais, mortality of all treatments reached at $100 \%$ at $36 \mathrm{~h}$. Therefore, the mortality rate that was obtained by contact with a surface of treated container of petri dish or glass jar with the 3 selected essential oils given highest at $36 \mathrm{~h}$. Aslan et al. (2004) reported that the level of mortality has been reached at $48 \mathrm{~h}$ with the essential oils of Achillea biebersteinii Afan and A. wilhelmsii, and at $96 \mathrm{~h}$ with oil of Pistacia spp. (Aslan et al., 2004).

These experimental were conducted to determine whether the insecticidal activity of the 3 selected essential oils were attributable to fumigant activity. In all cases, considerable differences in insect mortality were noted with different doses and exposure times as shown on Figures 1 and 2. It can be concluded that for control of S. zeamais, higher doses for a relatively short period are much more effective than lower doses for longer periods. Fumigant toxicity of the three essential oils to bruchid increase of exposure time from 6 to $48 \mathrm{~h}$ resulted in an increase of larval mortality, whilst further increases of exposure time gave no additional detrimental effect (Papachristos and Stamopoulos, 2002).

\section{CONCLUSION}

In conclusion, essential oil of Acacia farnesiana, Ocimum basilicum L. and Illicium verum Hook had fumigant toxicity on Sitophilus zeamais Motshulsdy. All essential oils are toxic for adults of $S$. zeamais, whether by exposure to the surface of the treated container petri dish or exposure to the surface of the treated container glass jar.

\section{ACKNOWLEDGEMENTS}

The authors would like to express our gratitude to the
Higher Education Research of Thailand (HERT) for grants for this research. We also would like to express our sincere gratitude to Naresuan University, Thailand, for funding support and providing laboratory facilities.

\section{REFERENCES}

Abbott WS, 1925. A method of computing the effectiveness of an insecticide. J Econ Entomol, 18:265-266.

Aslan I, Özbek H, Kordali S, Çalmaur Ö, Çakir A, 2004. Toxicity of essential oil vapors obtained from Pistacia spp. to the granary weevil, Sitophilus zeamais (L.) (Coleoptera: Curculionidae). J Plant Dis Prot, 111: 400-407.

Bittner M, Casanueva ME, Arbert C, Aguilera M, Hernandez V, Becerra $J, 2008$. Effects of essential oils from five plants species against the granary weevil Sitophilus zeamais and Acanthoscelides obtectus (Coleoptera). J Chilean Chem Soc, 53: 1455-1459.

Champ BR, Dyte CE, 1977. FAO global survey of pesticide susceptibility of stored grain pests. FAO Plant Protection Bull, 25: 4967.

Dhliwayo T, Pixley KV, 2003. Divergent selection for resistance to maize weevil in six maize populations. Crop Sci, 43:2043-2049.

EPA, 2001. Protection of stratospheric ozone: process for exempting quarantine and preshipment applications of methyl bromide. United State Environmental Protection Agency, Federal Register 66, pp. 37752-37769.

Fikremariam A, Tadele T, Stephen M, Yoseph B, Stefan V, 2009. Resistance of maize varieties to the maize weevil Sitophilus zeamais (Motsch.) (Coleoptera: Curculionidae). Afr J Biotechnol, 8: 5937-5943.

Giga DP, Mutemerewa S, Moya G, Neeley D, 1991. Assessment and control of losses causes by insect pests in small farmers stores in Zimbabwe. Crop Prot, 10, 287-292.

Isman MB, 2006. Botanical insecticides, deterrents, and repellents in modern agriculture and an increasingly regulated world. Annu Rev Entomol, 51: 45-66.

Keba T, Sori W, 2013. Differential resistance of maize varieties to maize weevil (Sitophilus zeamais Motschulsky) (Coleoptera: Curculionidae) under laboratory conditions. J Entomol Sci, 10: 1-12.

Kim SII, Roh JY, Kim DH, Lee HS, Ahn YJ, 2003. Insecticdal activities of aromatic palnt extracs and essential oils against Sitophilus oryzae and Callosobruchus chinensis. J Stored Prod Res, 39: 293-303.

Kouninki H, Hance T, Noudjou FA, Lognay G, Malaisse F, Ngassoum MB, 2007. Toxicity of some terpenoids of essential oils of Xylopia aethiopica from Cameroon against Sitophilus zeamais Motschulsky. J Appl Entomol, 131: 269-274.

Lee $\mathrm{BH}$, Annis $\mathrm{P}$, Tumaalii $\mathrm{F}$, Lee S, 2003. The potential of 1,8-cineole as a fumigant for stored wheat, p. 230-234. In Proceedings of the Australian Postharvest Technical Conference, Canberra. 25-27 June 2003. Commonwealth Scientific and Industrial Research Organisation (CSIRO), Canberra, Australia.

Longstaff BC, 2010. Biology of the grain pest species of the genus Sitophilus (Coleoptera: Curculionidae), A critical review. Prot Ecol, 1981, 2: 83-130.

Miresmailli S, Bradbury R, Isman M, 2006. Comparative toxicity of Rosmarinus officinalis $\mathrm{L}$. essential oil and blends of its major constituents against Tetranychus urticae Koch (Acari: Tetranychidae) on two different host plants. Pest Manag Sci, 62: 366-371.

Muzemu S, Chitamba J, Goto S, 2013. Screening of stored maize (Zea mays L.) varieties grain for tolerance against maize weevil, Sitophilus zeamais (Motsch.). Int J Plant Res, 3:17-22.

Papachristos DP, Stamopoulos DC, 2002. Toxicity of vapours of three essential oils to the immature stages of Acanthoscelides obtectus (Say) (Coleoptera: Bruchidae). J Stored Prod Res, 38: 365-373.

Pingali PL, Pandey S, 2001. Meeting world maize needs: technology opportunities and priorities for the public sector, In: Pingali, P.L. (Ed.), World Maize Facts and Trends. Meeting World Maize Needs: Technological Opportunities and Priorities for the Public Sector. CIMMYT, Mexico City. CIMMYT 1999-2000, 2001.

Regnault RC, 1997. The potential of botanical essential oils for insect pest control. Integrat Pest Manag Rev, 2: 25-34. 
Suleiman R, Rosentrater KA, Bern CJ, 2015. Evaluation of maize weevils Sitophilus zeamais Motschulsky. infestation on seven varieties of maize. J Stored Prod Res, 64: 97-102.

Ukeh DA, Birkett MA, Bruce TJA, Allan EJ, Pickett JA, Mordue Luntz AJ, 2010. Behavioral responses of the maize weevil, Sitophilus zeamais, to host (maize grain) and non-host plant volatiles. Pest Manag Sci, 66: 44-50.

Vanichpakorn $P$, Vanichpakorn WD, Cen XX, 2010. Insecticidal activity of five Chinese medicinal plants against Plutella xylostella L. larvae. J Asia-Pacific Entomol, 13: 169-173.

Vedovatto F, Valério Júnior C, Astolfi V, Mielniczki PAA, Roman SS, Paroul N, Cansian RL, 2015. Essential oil of Cinnamodendron dinisii Schwanke for the control of Sitophilus zeamais Motschulsky (Coleoptera: Curculionidae). Rev Bras Plantas Med, 17(4) supl.3 Botucatu.

Vogel H, Razmilic I, Doll YU, 1997. Contenido de aceite esencial y alcaloides en diferentes poblaciones deboldo (Peumus boldus Mol.). Ciencia e Investigación Agraria, 24:1-6.

Vogel H, Razmilic I, San Martín J, Doll U, González YB, 2005. Plantas medicinales chilenas., 192 p. Editorial Universidad de Talca, Talca, Chile.

Wang YN, Shi GL, Zhao LL, Liu SQ, Yu TQ, Clarke SR, Sun JH, 2007. Acaricidal activity of Juglans regia leaf extracts on Tetranychus viennensis and Tetranychus cinnabarinus (Acari: Tetranychidae). J Econ Entomol, 100: 1298-303.

Wink M, 1993. Production and application of phytochemicals from an agricultural perpective. In: van Beek, T.A., Breteler, M. (Eds.), Phytochemistry and Agriculture, Vol.34. Clarendon, Oxford, UK, pp. 171-213.
Citation: Pangnakorn U, Chuenchooklin S, 2018. Evaluation of essen tial oils against Sitophilus zeamais (Motshulsdy) (Coleoptera: Curculi onidae). Adv Med Plant Res, 6(2): 19-25. 